\title{
Tumor Cell Invasion
}

National Cancer Institute

\section{Source}

National Cancer Institute. Tumor Cell Invasion. NCI Thesaurus. Code C20625.

The local spread of tumor cells of a malignant neoplasm through infiltration or destruction of adjacent tissue; for epithelial neoplasms, invasion signifies infiltration beneath the epithelial basement membrane. 